Required software to e-Annotate PDFs: Adobe Acrobat Professional or Adobe Reader (version 11 or above). (Note that this document uses screenshots from Adobe Reader DC.)

The latest version of Acrobat Reader can be downloaded for free at: http://get.adobe.com/reader/

Once you have Acrobat Reader open on your computer, click on the Comment tab (right-hand panel or under the Tools menu).

This will open up a ribbon panel at the top of the document. Using a tool will place a comment in the right-hand panel. The tools you will use for annotating your proof are shown below:

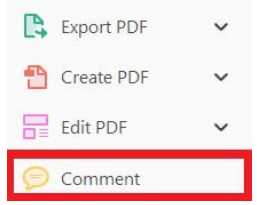

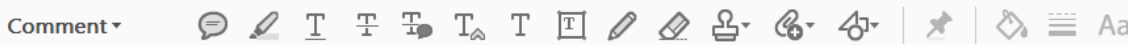

1. Replace (Ins) Tool - for replacing text.

T. Strikes a line through text and opens up a text box where replacement text can be entered.

How to use it:

- Highlight a word or sentence.

- Click on $T_{D}$.

- Type the replacement text into the blue box that appears.

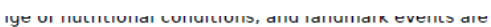
nitored in populations of relatively homogeneous single $\mathrm{n}$ of

and Is initiated atter

carbon source [ 1]. S

are referred to as mei

rof meiosis-specific

inducer of meiosis) [3

I

1 functions as a repre

repression, the genes

pression) and RGRI a।

rase II mediator subur

irectly or indirectly re

Post jstaddon.

Reply $x$

Reply $X$

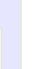


5. Attach File Tool - for inserting large amounts of text or replacement figures.

Inserts an icon linking to the attached file in the Q appropriate place in the text.

How to use it:

- Click on $\&^{\text {- }}$

- Click on the proof to where you'd like the attached file to be linked.

- Select the file to be attached from your computer or network.

- Select the colour and type of icon that will appear in the proof. Click OK.

The attachment appears in the right-hand panel.

:hondrial nreparatior ative da ie extent of membra I, malondialdehyde ( (TBARS) formation.' inad bu biak marfam
6. Add stamp Tool - for approving a proof if no corrections are required.

$\Omega$ Inserts a selected stamp onto an appropriate place in the proof.

How to use it:

- Click on $\Omega$.

- Select the stamp you want to use. (The Approved stamp is usually available directly in the menu that appears. Others are shown under Dynamic, Sign Here, Standard Business).

- Fill in any details and then click on the proof where you'd like the stamp to appear. (Where a proof is to be approved as it is, this would normally be on the first page).

)t the Dusiness cycie, starting with the on perfect competition, constant ret

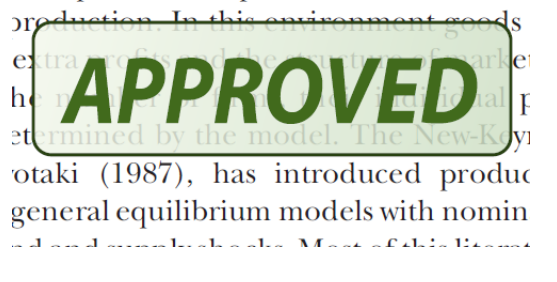

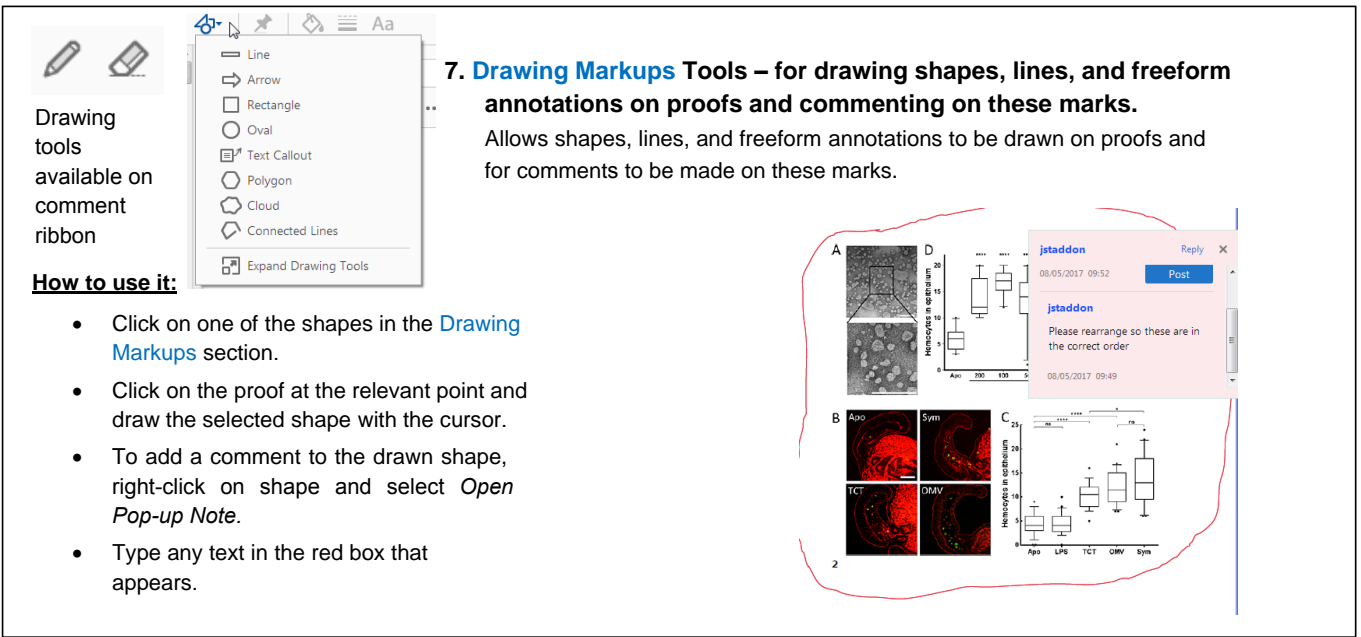

For further information on how to annotate proofs, click on the Help menu to reveal a list of further options:

Welcome...

?) Learn Adobe Acrobat Reader DC..

About Adobe Acrobat Reader DC...

About Adobe Plug-Ins...

Generate System Report...

Repair Installation

Check for Updates... 


\section{Author Query Form}

Journal: ANTI

Article: 12382

Dear Author,

During the copyediting of your manuscript the following queries arose.

Please refer to the query reference callout numbers in the page proofs and respond to each by marking the necessary comments using the PDF annotation tools.

Please remember illegible or unclear comments and corrections may delay publication.

Many thanks for your assistance.

\begin{tabular}{|l|l|l|}
\hline $\begin{array}{l}\text { Query refer- } \\
\text { ence }\end{array}$ & Query & Remarks \\
\hline 1 & $\begin{array}{l}\text { AUTHOR: Please confirm that given names } \\
\text { (red) and surnames/family names (green) } \\
\text { have been identified correctly. }\end{array}$ & \\
\hline 2 & $\begin{array}{l}\text { AUTHOR: Should the text citation Harvey } \\
\text { (2003) be changed to (2005)? }\end{array}$ & \\
\hline 3 & $\begin{array}{l}\text { AUTHOR: Should the text citation BBSR } \\
\text { (2011) be changed to (2007)? }\end{array}$ & \\
\hline 4 & $\begin{array}{l}\text { AUTHOR: Please give reference details for } \\
\text { Barkow and Georgi (2014). }\end{array}$ & \\
\hline 5 & $\begin{array}{l}\text { AUTHOR: Please give reference details for } \\
\text { IFRA (2014). }\end{array}$ & \\
\hline 6 & $\begin{array}{l}\text { AUTHOR: Please give reference details for } \\
\text { Immeo (2014). }\end{array}$ & \\
\hline
\end{tabular}




\title{
The Financialisation of Rental Housing 2.0: Releasing Housing into the Privatised Mainstream of Capital Accumulation
}

1

\author{
Gertjan Wijburg
}

Division of Geography and Tourism, KU Leuven, Leuven, Belgium;

gertjan.wijburg@kuleuven.be

Manuel B. Aalbers

Division of Geography and Tourism, KU Leuven, Heverlee, Belgium

\section{Susanne Heeg}

Institute of Human Geography, Goethe-Universitat Frankfurt am Main, Frankfurt am Main, Germany

\begin{abstract}
This article presents two cases of listed real estate companies that operate in the Ruhr metropolitan region of Germany. The first is Immeo Wohnen, a subsidiary of the French real estate investment trust (REIT) Foncière des Régions that was previously owned by a US hedge fund. The second is Vonovia, Germany's largest real estate company, originally a subsidiary of a British private equity firm. Both examples embody what we call the shift from financialisation 1.0 to financialisation 2.0, i.e. the transition from pure speculation to long-term investment. We show that long-term investment strategies are used by REITs and listed funds in order to release housing into the privatised mainstream of capital accumulation. With the advent of the financialisation of rental housing 2.0, the long-term investment focus of these funds paradoxically enables a short-term investment focus by buying and selling shares in these funds on the stock exchange.

Kurzfassung: In diesem Beitrag werden zwei im Ruhrgebiet tätige börsennotierte Wohnungsgesellschaften in den Blick genommen. Die erste Aktiengesellschaft ist Immeo Wohnen, eine Tochtergesellschaft des französischen Real Estate Investment Trusts (REIT) Foncière des Régions, die sich zuvor im Besitz eines US-amerikanischen Hedge Fonds befand. Das zweite Wohnungsunternehmen ist Vonovia, das gegenwärtig größte Wohnungsunternehmen in Deutschland. Ursprünglich war Vonovia ein Ableger einer Britischen Privat-Equity-Gesellschaft. Beide Beispiele stehen für das, was wir als eine Verschiebung von Finanzialisierung 1.0 zu Finanzialisierung 2.0 bezeichnen, d.h. der Übergang von reiner Spekulation zu langfristigem Investment. Wir argumentieren, dass langfristige Investmentstrategien von REITs und Aktiengesellschaften darauf zielen, Wohnen in den privatisierten Mainstream der Kapitalakkumulation zu überführen. Allerdings wird der langfristige Investmentfokus beider Aktiengesellschaften mit Beginn von Finanzialisierung 2.0 von einem kurzfristig orientierten Börsenhandel der Aktien dieser Gesellschaften begleitet.
\end{abstract}

Keywords: financialisation, gentrification, Germany, primitive accumulation, private equity and hedge funds, rental housing 


\section{Introduction}

In Germany, Spain, the US and elsewhere, a new set of landlords has entered the rental housing market: private equity firms, hedge funds, real estate investment trusts (REITs) and publicly listed real estate firms. We refer to the original acquisition of different forms of decommodified and not-fully commodified housing (public, social, cooperative, rent-stabilised and company housing) ${ }^{1}$ by private equity funds and other opportunistic investment funds as financialisation 1.0. Like land grabbing (Ince 2014), it is one of the forms of land enclosures or primitive accumulation of the early $21^{\text {st }}$ century. The subsequent phase 2.0 starts with the conversion to REITs and listed real estate firms.

The financialisation of rental housing 1.0 largely took place in the seven years before the global financial crisis (GFC) of 2007 and is associated with short-term investment strategies of "buying low and selling high" (Fields and Uffer 2016; Holm 2010b). Private equity firms operate in a financial web of multiple actors, loans and securitisations, which makes it difficult to conceptualise who really is the landlord and to whom tenants should address their grievances. Private equity firms have a short-term focus (three to five years), are highly leveraged (i.e. loaded with borrowed money and little equity) and typically invest little in maintenance (Diamantis 2013; Fields 2015). Some of their real estate acquisitions are so over-leveraged that the average rent per unit is lower than the cost of servicing the debt per unit, i.e. the rent does not even cover the interest on the loans that were taken out to acquire these properties in the first place (Fields 2015; Holm 2010a; Uffer 2011).

However, in cities like New York and Berlin the financial expectations of the private equity firms often did not materialise. Making money on subsidised rental housing turned out to be harder than expected. Some of these firms simply have collapsed, others had to readjust their strategies: both rents and sales brought in less money than expected and buy-, hold- and sell-plans had to be adjusted accordingly (Fields 2015; Fields and Uffer 2016). As a result of the GFC, accessing external finance, crucial for the business models of private equity real and hedge funds, became so difficult that most were forced to sell off their portfolios (Aalbers 2016). However, financialisation did not stop or halt; many private equity funds were converted into REITs and listed real estate companies, and housing portfolios were sold directly to listed real estate funds (Wijburg and Aalbers 2017a). Here we focus on the financialisation of rental housing 2.0, i.e. the takeover of housing portfolios by REITs and listed real estate funds.

Unlike private equity and hedge funds, REITs and listed real estate companies appear to adopt a long-term investment strategy to create stable cash flows for their shareholders (Lizieri 2009). They seek to create a "rentier structure" to optimise cash flows, rental incomes and capital gains through the sale of individual housing units (Moreno 2014; Rutland 2010). Second, they seek to enhance the net value of the portfolio, for instance through focusing on core investment strategies, stimulating gentrification effects through modernisations and refurbishments, "gaming" rental regulations and teaming up with local authorities to coordinate neighbourhood development (Bernt et al. 2017; Beswick et al. 2016). Instead of the "pure" speculative strategies of "buy low and sell high", the new 
landlords focus on long-term real estate management. Nevertheless, also REITs and listed real estate companies are primarily aimed at extracting (potential) value from former decommodified and not fully-commodified housing.

We argue that the shift towards financialisation 2.0 does not signify a radical break with financialisation 1.0, but rather a continuation with different means and strategies. We show that the more aggressive phase of financialisation 1.0 was a prerequisite to launch the "expanded reproduction" of dispossessed housing as an income-producing financial asset. Albeit qualitatively different, both stages are part of the "ongoing process of social reconfiguration that imposes logics of (fictitious) commodification and fictitious capital formation on land" (AlShehabi and Suroor 2016:837-838). Therefore, we also show that the boundaries between 1.0 and 2.0 and, accordingly, between private equity and hedge funds on the one hand, and REITs and listed real estate companies on the other, are not as clear-

2 cut as they seem and that both stages make up for what Harvey (2003) considers a wider pattern of "accumulation by dispossession". Like earlier forms of accumulation, financialisation 2.0 "entail[s] taking land ... and then releasing the land into the privatised mainstream of capital accumulation" (Harvey 2005:145). ${ }^{2}$ More precisely, it entails a stage of capital accumulation in which rental housing units are no longer treated as purely speculative goods but rather as long-term investment objects for investment funds. Paradoxically, the long-term investment focus of these funds enables a short-term investment focus by buying and selling shares in these funds on the stock exchange.

Although the arrival of listed real estate companies is recognised as an important development, the rise of financialisation 2.0 remains under-studied in the literature. Against the background of austerity urbanism and the ongoing expansion of international capital markets into housing and real estate (Fernandez and Aalbers 2016; Peck 2012), this could be considered a shortcoming. On the one hand, there are several urban case studies which have highlighted how former decommodified housing portfolios have been sold to financial investors (Bernt et al. 2017; Beswick et al. 2016; Fields and Uffer 2016; García-Lamarca 2017; Teresa 2016). ${ }^{3}$ Yet, these studies focus primarily on financialisation 1.0 and have only hinted at the rise of the next phase: financialisation 2.0. On the other hand, there are a couple of studies that focus on REITs and listed real estate companies in Germany, France and Ireland (Byrne 2016; Holm 2010a; Waldron 2017; Wijburg and Aalbers 2017b). However, the latter studies are national in scope and neither focus on local investment strategies, nor on the urban processes shaping financialisation 2.0.

We scrutinise these processes through an analysis of the investment activities of a REIT and a listed firm in Germany: Immeo Wohnen and Vonovia. Immeo is a subsidiary of the French REIT Foncière des Régions (FdR) that entered the German market in 2005 after it purchased a 39,400 unit large housing portfolio from a hedge fund of US investment bank Morgan Stanley. The second company, Vonovia, is the largest listed real estate company in Germany. Until 2015, the company was known as Deutsche Annington and belonged to the British private equity firm Terra Firma Capital Partners. Both companies operate in the Ruhr area, the region where the largest number of housing units in Germany were sold to financial 
investors between 1999 and 2008 (BBSR 2007; Diamantis 2013; Kofner 2012). FdR is currently selling most of its remaining housing assets here as it conducts a "core investment strategy" and relocates its business activities to more profitable areas, such as Berlin and Hamburg. Although Vonovia's overall strategy is broadly similar, the company is currently engaged in the redevelopment of a neighbourhood in Essen. Using government aid and modernisation techniques, Vonovia adopts a gentrification strategy to enhance the real estate values by gaming the system of rental housing regulations.

By describing the shift from financialisation 1.0 to 2.0, this paper adds to the literature on the financialisation of rental housing (Aalbers 2016; Bernt et al. 2017; Beswick et al. 2016; Fields and Uffer 2016; Soederberg 2017; Wijburg and Aalbers 2017a) but also contributes real-world examples to the literature that argues that real estate increasingly is managed as an object of investment (Coakley 1994; Lizieri and Pain 2014; Van Loon and Aalbers 2017) and more generally to the a strand of the financialisation literature that argues that profitmaking occurs increasingly through financial channels rather than through trade and commodity production (Krippner 2011). Because the advent of financialisation 2.0 coincides with wider transformations in the financial sector and urban political economy (cf. Botzem and Dobusch 2017), we conclude that the described transition also exemplifies how international finance and the stock exchange intensify their control over the management and production of urban space and local real estate markets (cf. Moreno 2014; Rutland 2010). We demonstrate this by adopting an actor-centred research approach and by focusing on the local investment strategies of Immeo Wohnen and Vonovia in the Ruhr area of Germany.

This paper has adopted a mixed case study design. Newspaper articles, policy documents and annual reports have been investigated to explore the investment practices of Immeo and Vonovia in Mülheim an der Ruhr and Essen. In order to fully comprehend the local investment practices of both companies we also conducted 14 semi-structured, in-depth interviews with various city councillors, urban planners, tenant associations, housing activists, but also with general managers and project managers of Immeo and Vonovia between October and December 2016. The next section provides a contextual history of housing privatisation in Germany. We then discuss the local investment practices of FdR and Vonovia in Mülheim an der Ruhr and Essen. We conclude by summarising the business strategies of listed real estate companies and explain how these strategies, together with other developments in rental housing, constitute financialisation 2.0.

\section{From Financialisation 1.0 to Financialisation 2.0}

During the late $19^{\text {th }}$ century, a subsidised private rental sector emerged in German cities (Harloe 1995; Kohl 2015). Mortgage banks, manufacturing firms, private developers and local municipalities were responsible for the construction of large-scale social housing associations (see also Voigtländer 2010). After World War II, subsidised rental housing became a cornerstone of post-war housing policies in the Federal Republic of Germany (Kofner 2014). ${ }^{4}$ Facing a permanent 
housing shortage, in part a result of war damage, the federal government vastly supported the construction of affordable housing (Voigtländer 2010). Affordable housing, typically managed by private or municipal companies, was seen as an integral part of Germany's post-war "social market economy" (Kofner 2014). The law of the Wohnungsgemeinnützigkeit ("common interest principle") guaranteed that social housing companies were exempt from taxation, providing that they served a public goal and offered affordable, rental housing units (Voigtländer 2010).

However, during the 1980s the state support for subsidised rental housing was heavily debated. The Kohl administration argued that it was necessary to reduce public expenditure to the subsidised housing sector and to promote "free" competition (Holm 2015). A new law, introduced in 1989, abolished the "common interest principle". Upon German reunification, social housing companies lost their protected status and were forced to become market-oriented and to introduce market logics to make the provision of housing possible (Voigtländer 2007). ${ }^{5}$ As a result, many municipal and industrial housing companies divested their real estate portfolios in order to pay off municipal debt or to raise shareholder value (Kirchner 2007; Voigtländer 2010). Between 1999 and 2011, around 1.4 million housing units were sold off (BBSR 2011), almost 3.5\% of the entire housing stock in Germany. Such sales took place in both East and West Germany; and in both economically weak and strong regions.

The reforms in the subsidised rental sector opened up the market to international investors: the financialisation of rental housing 1.0. Although it was not the goal of the German government to facilitate these investors, their entry into the German housing market is the contingent outcome of state restructuring, welfare reforms and housing privatisation that created new state-market relations (Bernt et al. 2017). The first international investors that entered the German housing market were US- and UK-based private equity and hedge funds (Aalbers and Holm 2008; Kaiser 2008; Voigtländer 2007). These funds create and manage real estate portfolios by collecting investment capital and leveraging it with credit from investments banks or the shadow banking system. Operating with little equity and high leverage ratios, private equity funds aim to make high returns but are also exposed to high default risks (Fichtner 2014; Kofner 2012). Their business model is based on "buying low and selling high"-i.e. on speculation in its purest form-and revolves around the usage of complex financial instruments and measurements (Deeg and Hardie 2016; Kofner 2012). Private equity funds aim to reduce vacancy rates and extract higher rents while deliberately disregarding maintenance, sometimes even when the older housing units of their portfolio are eroding (Botzem and Dobusch 2017; Holm 2010b).

In Germany privatisation and financialisation happened throughout the country, but more intensely in some regions such as Berlin because of the large public housing stock and the dire budgetary crisis of the State of Berlin. Not only did the 19 different public housing companies sell off thousands of units, two companies were completely privatised. With the 2004 purchase of GSW and its 65,000 units, Cerberus, an American private equity firm valued at $\$ 24$ billion, became the largest landlord of Berlin overnight. Valued at $€ 405$ million, the deal allowed 
Cerberus to purchase the stock at a mere $€ 6230$ per housing unit, although Cerberus also took on GSW's debt. The company acquired another 30,000 units in at least nine different transactions (Aalbers and Holm 2008). Cerberus was backed by Goldman Sachs' real estate subsidiary Whitehall Funds. Cerberus and Whitehall had planned to hold GSW and the other 30,000 units for a few years, raising rents, upgrading and selling a number of units in gentrified neighbourhoods (Uffer 2011), while reducing maintenance costs elsewhere.

During the mid 2000s and in particular since the GFC, many private equity and hedge funds have exited the German housing market (Müller 2012; Scharmanski 2013). However, most housing portfolios were not sold directly to new investors. Instead, several funds transformed their housing subsidiaries into independent housing companies that became listed on the Frankfurt Stock Exchange, allowing the private equity and hedge funds to exit the German housing market (Heeg 2013; Kofner 2012). For instance, Cerberus managed to bring GSW to the stock exchange, marking the shift to financialisation 2.0. The IPO of GSW was valued at $€ 468$ million, undoubtedly less than Cerberus and Whitehall Funds had counted on, but assuming these firms have loaded GSW further with debt than it already was when Cerberus bought it in 2004, both companies probably still realised a handsome profit. Other funds struggled with meeting the high interest payments on their offshore credit loans and defaulted in the wake of the crisis (Botzem and Dobusch 2017). The shift from private equity and hedge funds to REITs and listed real estate was followed by a wave of mergers and acquisitions, resulting in a select group of listed companies and REITs: Vonovia, Deutsche Wohnen, LEG Immobilien and Foncière des Régions (Immeo Wohnen) are four major players with a quasi-monopoly position. In 2013 the total size of the listed real estate sector in Germany, 75\% of which is residential (Barkow and Georgi 2014), was valued at €1,833 billion (EPRA 2013).

Unlike private equity funds, listed real estate companies adopt a mid- to long-term approach of managing and maintaining income-producing real estate assets (Kofner 2012). Much like REITs, listed real estate companies are legally obliged to distribute the largest part of their operative income to their shareholders (Lizieri 2009). ${ }^{6}$ While shareholders expect a maximisation of shareholder value, listed real estate companies typically seek returns of 4-6\% annually and are thus devoted to creating continuous cash flow and operative income by renting out housing units and selling individual units at profitable prices (Heeg 2013; IEIF 2014). In doing so, listed real estate companies and REITs alike are known for developing strategies to enhance the real estate values of their portfolio, sometimes by gaming the systems of rental regulations (Kofner 2012; Lizieri 2009), as will become clear in the next section. These strategies of "expanded reproduction" can be considered as a continuation of the more "primitive" strategies of private equity funds, albeit with different means and considering a longer time frame (cf. AlShehabi and Suroor 2016).

Nonetheless, it must be emphasised that the boundaries between private equity and hedge funds on the one hand and REITs and listed real estate companies on the other are not as clear-cut as it seems. For instance, Bernt et al. (2017) have shown how private equity funds can make money through receiving statesubsidised rents to house unemployed welfare recipients. Providing that a housing 
shortage prevails and interest rates remain low, private equity funds can make money on this so-called "Hartz IV-model" as they offer low-cost and often lowmaintained housing units to this target group (see also Müller 2012). However, this model has also been adopted by various listed funds that seek to make longterm profits. Similarly, some private equity funds were already involved in property management before they sold off their portfolios or before their IPO; some listed funds still adopt private equity techniques and divest the less profitable parts of their housing portfolio (Kofner 2012). Increasing evidence also shows how both private equity funds and listed real estate companies engage in a tight network of supporting financial intermediaries, thus extending their activities far beyond the reach of the real estate industry alone and also generating income through fees, commissions and mortgage securitisation (Botzem and Dobusch 2017). Table 1 provides a summary of the investment strategies of REITs and listed real estate companies compared with both social housing companies, and private equity and hedge funds.

\section{Listed Real Estate Companies: FdR and Vonovia}

Since the aim of this paper is to identify local investment strategies that make up for expanded reproduction, this section focuses on two large listed real estate companies operating in the Ruhr area in the state of Nordrhein-Westfalen (NRW): Foncière des Régions (Immeo Wohnen) and Vonovia. While both companies adopt broadly similar investment approaches, they locally adjust their strategies to fully exploit the uneven geographies of the regional and urban economy of Germany. Table 2 displays the key figures and locations of both companies.

Before moving into the analysis, we want to emphasise that both companies can be considered as representative for all listed real estate companies in Germany which, as we have explained in the previous section, adopt broadly similar investment strategies regardless of the historical origin of their housing portfolio (public, municipal or industrial) but adjust these strategies according to the market

Table 1: Investment strategies of listed real estate companies in Germany

\begin{tabular}{|c|c|c|c|}
\hline $\begin{array}{l}\text { Company } \\
\text { structure }\end{array}$ & $\begin{array}{l}\text { Social housing } \\
\text { company }\end{array}$ & $\begin{array}{l}\text { Private equity and hedge } \\
\text { funds }\end{array}$ & $\begin{array}{l}\text { Listed real estate } \\
\text { companies/REITs }\end{array}$ \\
\hline \multicolumn{4}{|l|}{ Characteristics } \\
\hline Principal activity & $\begin{array}{l}\text { Providing affordable } \\
\text { housing for low- } \\
\text { and moderate- } \\
\text { income households }\end{array}$ & $\begin{array}{l}\text { Buying low and selling } \\
\text { high }\end{array}$ & $\begin{array}{l}\text { Managing and } \\
\text { maintaining income- } \\
\text { producing real estate } \\
\text { assets }\end{array}$ \\
\hline Debt structure & $\begin{array}{l}\text { Fiscal and financial } \\
\text { subsidies, bank } \\
\text { loans }\end{array}$ & $\begin{array}{l}\text { Low equity and high } \\
\text { debt, often through } \\
\text { offshore finance } \\
\text { (highly leveraged) }\end{array}$ & $\begin{array}{l}\text { Capital markets and } \\
\text { offshore finance }\end{array}$ \\
\hline Profit versus risks & Non-profit, long-term & $\begin{array}{l}\text { High risks, high profits, } \\
\text { short-term }\end{array}$ & $\begin{array}{l}\text { Medium profits, low to } \\
\text { medium risks, long- } \\
\text { term }\end{array}$ \\
\hline
\end{tabular}


Table 2: Key figures from Vonovia and Immeo Wohnen (source: based on annual reports and calculations by the authors)

\begin{tabular}{|c|c|c|}
\hline & FdR (Immeo Wohnen) & Vonovia \\
\hline Original owner & ThyssenKrupp steel company & $\begin{array}{l}\text { Railway and utility companies } \\
\text { (among others) }\end{array}$ \\
\hline $\begin{array}{l}\text { Private equity/hedge } \\
\text { fund }\end{array}$ & $\begin{array}{l}\text { Immeo Wohnen (Corpus/ } \\
\text { Morgan Stanley) }\end{array}$ & $\begin{array}{l}\text { Deutsche Annington (Terra } \\
\text { Firma) }\end{array}$ \\
\hline Net initial yield (EPRA) & $5,0 \%$ & $5,6 \%$ \\
\hline Market capitalisation & $\begin{array}{l}€ 18.4 \text { billion ( } € 2.1 \text { billion in } \\
\text { Germany) }\end{array}$ & $€ 13.3$ billion \\
\hline $\begin{array}{l}\text { Housing units under } \\
\text { management }\end{array}$ & 44,939 in Germany & 333,381 \\
\hline Geographical focus & $\begin{array}{l}\text { NRW }(52 \%), \text { Berlin }(34 \%), \\
\text { Dresden and Leipzig (8\%), } \\
\text { Hamburg }(6 \%)\end{array}$ & $\begin{array}{c}\text { Nationwide: in NRW }(31 \%), \\
\text { Leipzig and Dresden }(14 \%), \\
\text { Stuttgart (9\%), Berlin (9\%) }\end{array}$ \\
\hline
\end{tabular}

challenges and opportunities of the city or region in which the housing portfolio is located. Likewise, we want to emphasise that both firms are not uniquely "German" inasmuch as they translate global real estate practices into local investment strategies and hence adopt a similar business model as REITs and listed funds in other countries (cf. Aalbers 2016; Beswick et al. 2016). The German case is similar to transitions from financialisation 1.0 to 2.0 in countries such as Ireland, Spain, the UK and the US where, albeit in a different institutional environment, the ownership transfer from private equity to listed real estate also can be observed (see e.g. Beswick et al. 2016; Fields forthcoming; García-Lamarca 2017; Waldron 2017). However, whereas Vonovia is more representative for a listed real estate company launched on the stock exchange initiated by a private equity firm, Immeo Wohnen is more representative for a globally operating REIT which expands its real estate portfolio through acquisitions. Yet, Vonovia also strategically cooperates with important housing companies in other European countries such as France.

\section{Immeo Wohnen}

The housing portfolio of Immeo Wohnen consists of the former housing units of two steel companies: Thyssen and Krupp. After the two competitors merged in 1999, ThyssenKrupp decided to focus on its "core" activities. As a result, the housing portfolio in the Ruhr area was put up for sale. In 2004, the ThyssenKrupp portfolio of 48,000 housing units was sold to Corpus, a hedge fund owned by US investment bank Morgan Stanley for an estimated price of €2.1 billion (Kofner 2012). Morgan Stanley rebranded the housing portfolio into Immeo Wohnen. Morgan Stanley's goal was to improve the cash flow of Immeo in order to resell it during a future market upswing (Kaiser 2008). However, it was faced with high interest payments on loans it had obtained to finance the acquisition of the portfolio (Kofner 2012). As the company struggled with repaying its debts, in particular during the GFC, Morgan Stanley started selling some of its dwellings. In 2005-2006, FdR acquired Immeo for €1.8 billion. 
Founded in 1963, FdR was initially a property company that maintained a large parking garage in Metz (IEIF 2014). After some acquisitions and leaseback agreements in the 1980s and 1990s, it expanded its portfolio with residential units and also acquired commercial real estate properties from Axa, Telecom and other French multinationals (IEIF 2014). After its IPO at the Paris Stock Exchange in 2003, FdR began to diversify its portfolio further, also internationally. Focusing strategically on offices in France and Italy, on hotels throughout Europe and housing units in Germany, the company developed into one of the largest REITs of

5 Europe (IFRA 2014). By 2015, the portfolio of FdR consisted of commercial real estate in France (45\%) and Italy (17\%), residential real estate in Germany (20\%), hotels and hospitals in Europe (13\%) and other types of real estate (6\%). In 2015, the company's portfolio equalled a total market capitalisation of around $€ 13$ billion. A majority of the shares of FdR are owned by a consortium of shareholders, including Delfin Group (29\%), the holding company of Italian billionaire Leonardo del Vecchio, and three French insurance companies: Covéa Group (12\%), Crédit Mutuel Insurances (8\%) and Crédit Agricole (7\%). Parts of the company are still owned by Charles Ruggieri, its founder.

The entry of FdR into the German housing market was part of its wider strategy of

6 global diversification (Immeo 2014). While homeownership rates, rental price and house price levels in Germany were lower than in other European countries, the German housing market was considered full of potential. However, FdR soon realised that the Immeo portfolio was less profitable than it had anticipated. Since most of Immeo's housing units were located in the less dynamic Ruhr area, the surge in house prices and rents remained limited. As a result, FdR changed its investment strategy in 2009 (Boisnier 2011). Selling many of its "non-core" assets in the Ruhr area, the company relocated its investment activities to the metropolitan regions of Berlin, Dresden, Leipzig and Hamburg where house price dynamics were stronger (Wijburg and Aalbers 2017a). As a result, the dominant investment strategy of FdR can be characterised as a core investment strategy: a general withdrawal from the Ruhr area in order to expand in more booming regions, whereby the company only keeps those assets with a special value, as we will see in the next section. ${ }^{7}$

\section{Vonovia}

The housing portfolio of Vonovia was established after a merger between Deutsche Annington and Gagfah in 2015. Deutsche Annington was created in 2001 when British private equity fund Terra Firma acquired 64,000 housing units from the German Federal Railways. With its headquarters in Düsseldorf and Bochum, Deutsche Annington started expanding its portfolio and eventually acquired large housing companies in Berlin, Dresden and Leipzig (Holm 2010b). In 2005, the energy companies E.On (previously, Veba and Viag) and RWE sold their housing portfolios of respectively 138,000 and 4500 housing units, which also enlarged the company's housing portfolio in the Ruhr area (Kofner 2012:89). During the GFC, Deutsche Annington introduced the so-called Clear Water reform, consisting of the abolishment of regional contact centres, the digitalisation of rental leases and the dismissal of 300 employees (Kofner 2012). 
Furthermore, it was able to refinance $€ 4.3$ billion of outstanding debt in 2012 , at the time the largest commercial mortgage-backed security deal in Europe. In the German public debate, Deutsche Annington has often been portrayed as a grasshopper (Heuschrecken) that destroys the harvest, without sowing because it was a prime example of a private equity fund that increased rents while simultaneously neglecting maintenance (Holm 2010b).

Terra Firma never intended to stay in Germany for more than six to eight years. In 2013 Deutsche Annington was transformed from a subsidiary of Terra Firma into an independent company listed at the Frankfurt Stock Exchange. After Deutsche Annington merged with Gagfah in 2015, the company was transformed into Vonovia, a listed real estate company. The initial public offering of the company allowed Terra Firma to progressively reduce and sell its shares in the company. Since its IPO, about $28 \%$ of the company in 2015 is owned by a consortium of asset managers and banks, including Blackrock (8\%), Norges Bank (8\%), Lansdowne Partners (5\%), Deutsche Bank (4\%) and Sunlife Partners (3\%). This shareholder structure underlines the international dimension of listed real estate in Germany. Not only can global asset managers such as Blackrock influence the local business strategies of Vonovia through shareholder votes; a large share of the profits of Vonovia, i.e. the rents of tenants in Germany, flow out of the country and are absorbed into international capital circuits.

With the exit of Terra Firma, the new company of Vonovia started "focusing on scale advantages and offering mid-priced private rental housing" (Interview, Regional Ministry NRW, 2016). Another way of Vonovia increasing profits is through a strategy of insourcing services, such as internet, energy and repairs. By closing package deals with local companies, Vonovia is able to provide relatively affordable services to its tenants while also taking a cut themselves. Sometimes the service package of Vonovia is included in the rental contract. To counter its past reputation as a grasshopper, Vonovia also developed a strategy to improve customer satisfaction and its corporate image. For instance, many of the Clear Water reforms were reversed. Vonovia also started refurbishing and modernising its housing stock in low-income neighbourhoods and engaging with "neighbourhood development" (Quartiersentwicklung) (Vonovia 2015), typically as a strategy to increase rents, thereby increasing pressure on some low-income tenants to move.

\section{The Local Investment Strategies of Immeo and Vonovia}

In this section we present two local case studies to demonstrate what investment strategies Immeo and Vonovia have adopted. These cases point to how listed real estate companies adopt two main strategies to make profits: selling housing units at a lucrative price or renting them out while improving the net value of the portfolio. The first case is the Heimaterde, a neighbourhood in Mülheim an der Ruhr where Immeo Wohnen sells most of its housing assets and maintains only those that cannot be sold immediately or that are still profitable. The sale of the Heimaterde illustrates Immeo's wider investment strategy of relocating to more booming metropolitan regions outside the Ruhr metropolitan area, with the exception of Düsseldorf. The second case is Elting, a central neighbourhood in Essen. 
Because Vonovia recognised the potential of Elting, the company has entered into a public-private partnership with the City of Essen and other stakeholders to develop the neighbourhood by investing in the modernisation of the housing units. As such, Vonovia adopts a gentrification strategy to enhance the real estate values by gaming the system of rental housing regulations.

\section{Immeo in Mülheim an der Ruhr}

The Heimaterde (in English: "home ground" ${ }^{8}$ ) is a neighbourhood in Mülheim an der Ruhr of approximately 900 dwellings. It was built during the 1920s and 1930 s by workers of the steel company of Krupp according to the principles of the English garden city movement. During the reign of the Nazi regime the Heimaterde was collectivised and became fully owned by Krupp, the regime's weapon producer. After the war, Krupp remained owner and intended to sell parts of its housing portfolio in the 1980s. However, it first took a merger with Thyssen in 1999 until it eventually sold its housing subsidiary to Morgan Stanley in 2004 (Kaiser 2008). Morgan Stanley, immediately focused on increasing the earnings of the company, but sold Immeo to FdR one year later as it struggled with making profits and meeting interest payments (Kofner 2012).

Initially, FdR manifested itself as a long-term investor and focused on the maintenance of the Heimaterde, thereby securing real estate values and contributing to neighbourhood stability: "Immeo was not so much concerned with profit maximisation. At least from the political side, we could still talk to them and the issues of tenants were also taken seriously" (Interview, City Councillor I, 2016). The longterm commitment to the Heimaterde was also reflected in its ambition to develop some parcels of land in the Max Halbachstraße. Since the Heimaterde has rather large gardens, Immeo planned to use some of them for new housing construction and received permission from the municipality, provided that it would construct housing for senior residents of the Heimaterde (Hesselmann 2015).

However, in 2008, in the midst of the GFC, FdR decided to change its investment strategy. On the one hand, the company realised that the former ThyssenKrupp dwellings were not profitable enough: "We are currently selling individual housing units, mainly family apartments and those that are difficult to manage ... We also seek to divest our non-core assets, which are mainly larger housing estates located in Duisburg" (Interview, CEO of Immeo Wohnen, 2016). On the other hand, the company strategically relocated its investment activities to more dynamic metropolitan regions: "We mainly invest in inner cities, including Berlin, Dresden and Düsseldorf, that is to say, in smaller housing units, which have rental potential" (Interview, CEO of Immeo Wohnen, 2016). As the outcome of this wider development, large sales followed in 2008 in Essen and Oberhausen (Lindgens and Süselbeck 2012). Simultaneously, the company progressively acquired more dwellings in Berlin, Dresden, Leipzig and Hamburg.

The local strategy of Immeo can be characterised as an "exit strategy", similar to that of private equity funds (Diamantis 2013). However, whereas private equity funds anticipate an exit from the market, either through an IPO or a resale of the entire portfolio, Immeo mainly focuses on the sale of individual housing units, 
thereby seeking to realise profits on each transaction and using the money to fund new acquisitions elsewhere. Although data of housing transactions in Mülheim are not available, Immeo started selling family homes in the Heimaterde soon after it changed its investment strategy. As a city councillor mentioned: "Mülheim an der Ruhr is one of the greenest cities of the Ruhr area. There are large plots of land. People working in Düsseldorf or Essen want to come and live here. Real estate and land is in high demand" (Interview, City Councillor II, 2016). As both the CEO of Immeo and a local urban planner stress, several houses were also sold to existing tenants or their children.

The exit strategy also resulted in the termination of the Immeo plan to construct housing for seniors (Hesselmann 2015). In 2016 the company sold the land and its building plan to Engel \& Völkers, a private developer based in Hamburg. This created a problem for the municipality because the building plan was open to interpretation: "The development plan was not precise enough; it could be sold and reinterpreted by the new developer" (Interview, Urban Planner I, 2016). In other words, Engel \& Völkers could bypass some of the commitments Immeo had made and instead focus on the construction of more luxurious apartments with an underground car park. As such, the new homes that are currently under construction can be sold to any buyer regardless of age or income class. A city councillor confirmed: "The CEO had decided that rental houses for elderly no longer belonged to the 'core' business of Immeo: they sold the land for a good price" (Interview, City Councillor II, 2016).

Although FdR is selling part of its local portfolio, the company still owns several blocks in the Heimaterde. First, it owns a couple of retirement homes (see Figure 1) which are offered as "special-purpose properties" on their website. Although retirement homes are difficult to split and to sell as pieces, senior homes can be easily marketised since they are scare and equipped with added value, such as elevators or wheelchair accessibility. Against the background of a nationally and locally ageing society, Immeo can still profit from the demand for age-appropriate houses, without having to build those assets from scratch, and also receiving federal grants to finance renovations (see also Helbrecht and Geilenkeuser 2012). Furthermore, Immeo has recently installed new solar panels on the rooftop of the retirement homes. The costs of these modernisations can be charged to the tenants, allowing Immeo to increase the rents. ${ }^{9}$

Second, Immeo still owns a number of under-maintained blocks of flats. As private landlords in Germany receive federal subsidies to house welfare recipients below market prices, these low-cost and low-quality dwellings can still be made profitable, providing that the capital costs of the buildings are low (cf. Bernt et al. 2017). The case of the Heimaterde illustrates that a listed real estate company may combine a long-term "hold" strategy for its core assets with a "sell" strategy for its non-core assets, depending on location, rental potential, sale potential and government policies it can incorporate in its business model. Through the sale of non-core assets in NRW, FdR is able to collect the money for new acquisitions in more dynamic regions, including Berlin and Hamburg. Essentially, the company applies a "core investment strategy" characterised by divestments in NRW and investments in booming metropolitan areas. 


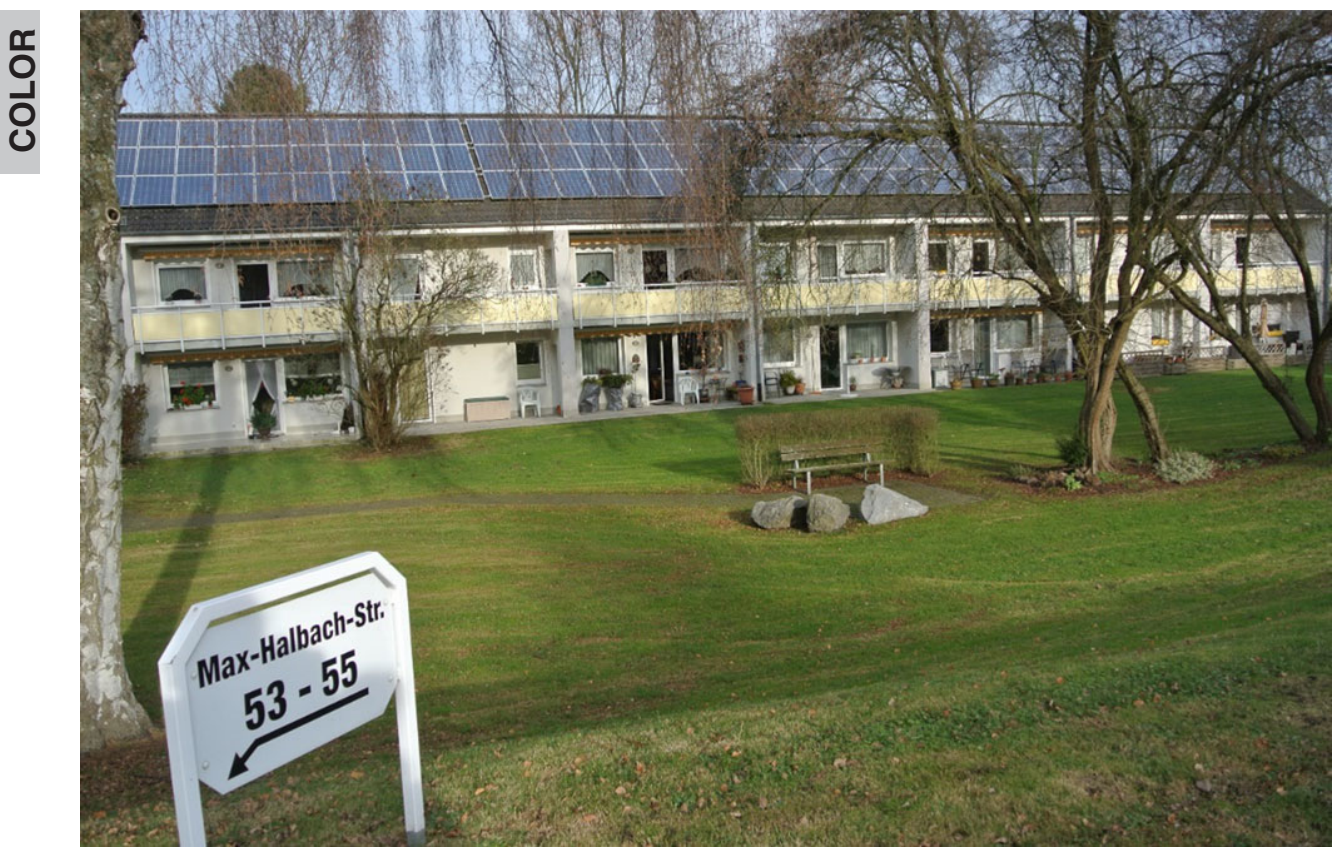

Figure 1: Max-Halbachstraße 53-55: one of the few remaining assets of FdR in Mülheim an der Ruhr (source: photo taken by Annia Martinez)

\section{Vonovia in Essen}

Vonovia's investment strategies in Essen's Elting neighbourhood are another paradigmatic example of financialisation 2.0. Once a lively working class neighbourhood, Elting was populated by the coalminers of RWE and railroad workers of Deutsche Bahn. After the coal crisis in 1957 and deindustrialisation, Elting slowly started to decline. While many workers lost their jobs, the neighbourhood got abandoned. From the 1970s onward, low-skilled migrants arrived in Essen and moved into Elting. The neighbourhood became known for its high unemployment rates and impoverished housing conditions. In 2016, more than one third of the population in the neighbourhood received welfare benefits and almost half of the population had a double or non-German nationality (Schymiczek 2015).

Vonovia owns around 3500 housing units in Elting and struggled to keep up its real estate values. As the neighbourhood was known as a "no go" area, Vonovia initially hired "guards to keep control in the neighbourhood" (Interview, Project Manager Elting, 2016). Yet, Elting was recognised as a neighbourhood with potential as it was relatively well located between the city centre and the University of Duisburg-Essen (Vonovia and CBRE 2016). At the same time, the energy company RWE and various other companies reopened their headquarters at the nearby Altenesesener Straße, thus providing local employment. Hence, Vonovia realised that there was not only potential in the neighbourhood, but also an opportunity to change its socio-economic structure. In the words of a project manager of Elting: "they had to do something for the stability of the neighbourhood, this was purely to secure the real estate values of Elting" (Interview, 2016). 
The first steps in the transformation of Elting had already been taken by Deutsche Annington when, in 2014, it approached a public-private entity named Innovation City. ${ }^{10}$ Innovation City operates largely in line with the Energy and Climate Plan adopted by the German federal government in 2008 in order to reduce $\mathrm{CO}_{2}$ emissions (Eckardt 2015). Central to the approach of Innovation City is the idea that "without a common effort, neighbourhood improvements cannot be made" (Interview, Innovation City, 2016). Vonovia and Innovation City laid the foundation for a development project based around the theme of "making Essen and Elting greener" (Interview, City Councillor II, 2016). First, it was negotiated that Vonovia would invest around €9.3 million in Elting in order to modernise around 1400 of its 3500 housing units. The renovations included energetic refurbishments, replacement of boilers, installations of double glazing and insulating external walls (Vonovia 2015). Second, the City channelled federal grants to the improvement of the neighbourhood and also agreed to pay rent increases for welfare recipients if the improvements allowed Vonovia to increase them over the thresholds defined in the Hartz IV-model of welfare.

The different actors involved agreed that neighbourhood development should not result in the displacement of existing tenants. It was argued that modernisation would result in lower energy expenses, which would compensate for higher rents. However, the development plan of Elting soon transformed into a prestige project of Vonovia, meant to improve its corporate image: "Vonovia has a bad image in Germany, they are under enormous pressure. For instance, to mobilise local support of residents, students and artists, Vonovia hired a project manager who would be in charge of "neighbourhood development" (Quartiersentwicklung) (Grenz 2016). In 2015 Vonovia also opened a pop-up art gallery, thereby providing an opportunity to local artists and students to exhibit their work locally (Hagenbucher 2016). Additionally, Vonovia installed new balconies in the better streets of Elting and equipped them with geraniums to please existing tenants (Hagenbucher 2016). Figure 2 shows the new balconies placed in the Victoriahof, a particular quarter of Elting where Vonovia and the City also develop a green courtyard.

However, the approach of neighbourhood development also caused some local controversies. In 2016 Vonovia announced its intention to replace a popular playground with a new child care centre (Grenz 2016). Some inhabitants and journalists feared that neighbourhood development of Vonovia was de facto a gentrification strategy (Böhnke 2015). With the combination of renovation, arts, neighbourhood branding and having the local and federal government pay for at least part of Vonovia's investments, it is not hard to see why its strategies where labelled gentrification. By forming a partnership with the municipality and other local stakeholders, Vonovia has succeeded in improving a well-located neighbourhood while only investing $€ 9.3$ million of its own resources.

At the same time, Vonovia is "playing" rental regulations. In 2013, the liberalconservative government introduced a new rental law in which private landlords are allowed to pass on environmental modernisation costs to their tenants. While doing so, the government has provided a leeway in Germany's rental regulation to increase the rents at a faster rate than normally is possible. As a representative of a tenant association confirmed: 


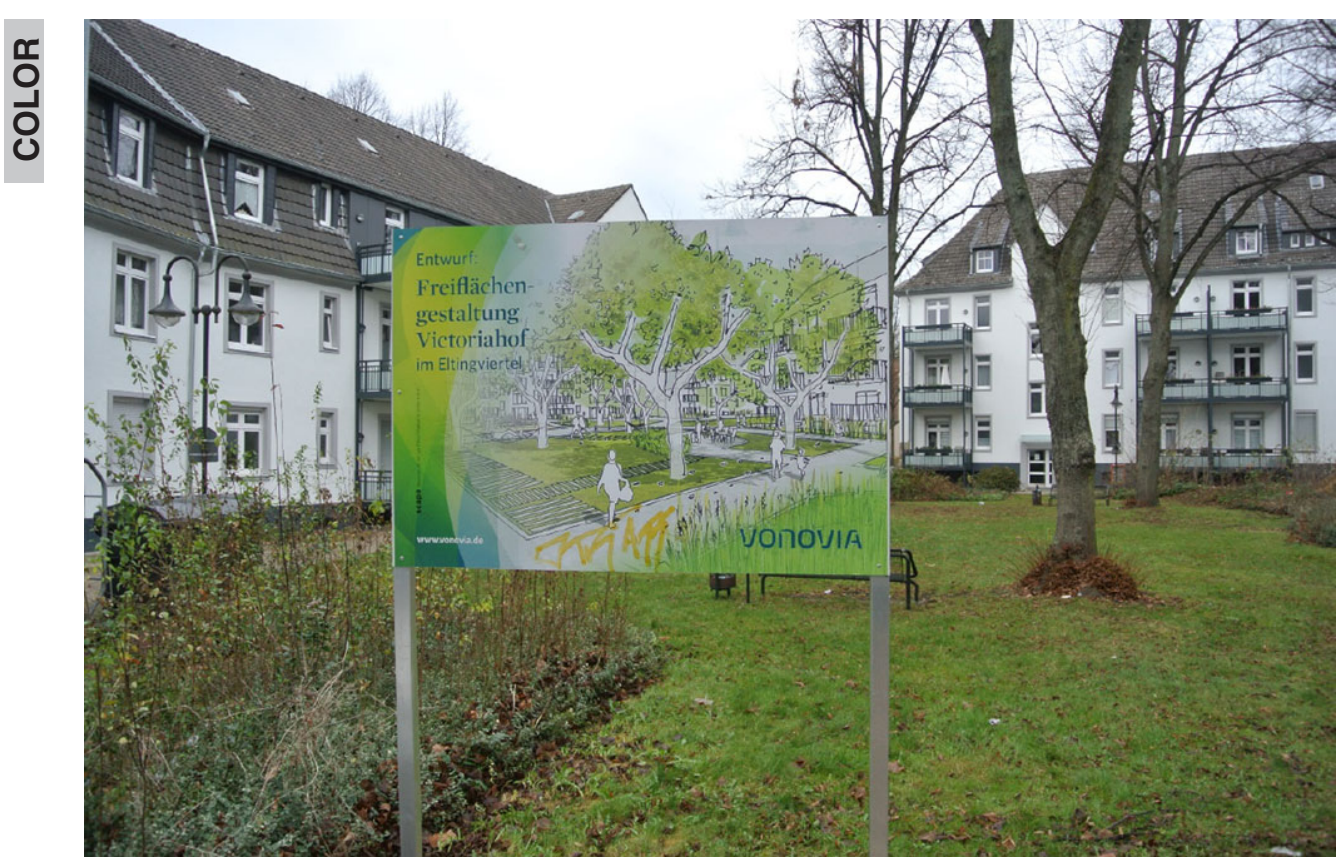

Figure 2: Victoriahof, Essen: Vonovia installs new balconies and co-finances a green courtyard (source: photo taken by Annia Martinez)

A private landlord in Germany is allowed to transfer eleven percent of modernisation costs [that are in line with the Energy and Climate Plan] to its tenant on an annual basis. After ten years [taking into account a low interest rate on loans], Vonovia has paid off its entire investment in Elting but the higher rental charges remain. Everything that follows is net profit. (Interview, Tenant Association, 2016)

In other words, Vonovia uses modernisation in their business model to raise rents in the Ruhr area and elsewhere in Germany (Unger 2017). Without modernisations, rents are only allowed to increase with a maximum of 302 over three years and not above the rental ceiling (Mietspiegel) of the neighbourhood (Deschermeier et al. 2016). ${ }^{11}$

Furthermore, Vonovia has found ways to game the rental regulations, a strategy reminiscent of those used by landlords of rent-stabilised apartments in New York (Aalbers 2016; Wyly et al. 2010). Private landlords in Germany are legally obliged to pay the maintenance costs of their housing units. However, in practice, the distinction between modernisation and maintenance is not always clear-cut. In the words of a representative of a tenant association:

The rental law says that it should be "comprehensible" what exactly belongs to maintenance or renovation costs. [However,] Vonovia sends a very detailed building plan of 300 pages, which due to its length and detail, is almost impossible to comprehend. We cannot verify how the maintenance and renovation costs are calculated. (Interview, 2016)

This spurs fierce protests among tenants, which are further ignited by the communication strategies of some of the larger funds. Vonovia is known for its 
automated and individualised announcements of rent increases and payment reminders, giving the impression of imminent eviction and increasing fear among tenants. Thus, the huge housing stock enables scale effects and strategies which smaller landlords do not have. This set-up, which will further drive up the costs of living, spurs gentrification and may also result in the displacement of low-income tenants when rents become unaffordable. This shows the real face of Vonovia's "modernisation strategy": neighbourhood development goes hand in hand with gentrification and displacement pressures.

\section{Conclusion}

In this paper we have introduced the concept of "the financialisation of rented housing $2.0^{\prime \prime}$ as a heuristic device to denote the shift in ownership from private equity funds and hedge funds to listed real estate companies and REITs. Whereas phase 1.0 is about enclosure or primitive accumulation $21^{\text {st }}$ century style - the commodification of fictitious commodities - and is a purely speculative strategy, phase 2.0 is about the treatment of housing as if it is a mainstream rather than fictitious commodity in the Polanyian sense (Polanyi 2001). Likewise, the massive privatisation of housing in many former socialist states (e.g. Murie et al. 2005) could be considered a case of primitive accumulation, but only when these units are being resold or mortgaged have they entered the privatised mainstream of capital accumulation. Furthermore, the buying out of favela dwellers in Brazil and the subsequent commodification of the land could be considered a form of primitive accumulation, whereas the rehousing of these people into mortgaged houses signifies the start of financialisation 2.0 (cf. Pereira 2017). By adopting an actorcentred approach and focusing on the investment and management strategies of two listed real estate companies, we have shown how these strategies have changed in Germany.

In the case of the Foncière des Régions, we find that that a REIT in a less dynamic market adopts a core investment strategy that results in selectively holding and selling properties. In the wake of the GFC, FdR decided to sell most of its housing assets in the Ruhr area and to refocus its investments on the more dynamic regions of Berlin and Hamburg where returns on investment are higher. Non-core properties, notably family houses in mid-sized cities as well as large housing portfolios in post-industrial cities like Duisburg and Oberhausen, are considered less attractive. The listed real estate company Vonovia, on the other hand, manages rental housing throughout Germany and makes additional investments in the Ruhr area. While Vonovia may not be implementing the aggressive policies of private equity and hedge funds and appears to be taking a long-term interest in neighbourhoods like Elting, its main goal is to create shareholder value. Government subsidies and rental regulations are employed and gamed to be able to increase rents. Even if this does not always result in direct displacement in the short run, thanks to local government guarantees, it does contribute to indirect displacement in the mid- to long-term.

Both cases show how REITs and listed real estate companies have moved progressively beyond the phase of speculative investment and appear to be 
interested in rental housing in the long run. Although they selectively withdraw from less dynamic regions, they define different core regions: whereas some focus on more dynamic regions with increasing housing prices and rents, others focus on less dynamic regions where they can monopolise local sub-markets. Within their core and non-core regions these companies also apply more local investment strategies. These landlords sell and hold properties selectively, depending on their location, rental potential and sale potential as well as the government policies and subsidies it can incorporate in its business model. In some cases, the rules of the welfare system are used to rent out low-quality housing to lowincome tenants (see also Bernt et al. 2017); in other cases they mobilise energy efficiency initiatives or gentrification pressures to increase rents. Both FdR and Vonovia have made arrangements with local governments to coordinate neighbourhood development or to invest in age-appropriate housing. While potentially benefitting local communities, such partnerships may also result in gentrification and displacement and clearly underline the important role of state authorities.

In this paper, we have demonstrated that financialisation 2.0 has not substituted or replaced financialisation 1.0, but rather has transcended it. However, our critical point here is that financialisation 1.0 and 2.0 are part of the same cycle of accumulation by dispossession, despite the fact that both stages are qualitatively different and involve different market actors and investment practices. As we have focused on the role of REITs and listed real estate companies, we have pointed out that these funds are in charge of the second stage of financialisation, i.e. with releasing housing into "the privatised mainstream of capital accumulation" (cf. Harvey 2005). In phase 1.0, private equity and hedge funds are engaged in pure speculative operations of buying low and selling high, and increasing the rents while neglecting maintenance. REITs and listed real estate companies have a longterm focus in which annual or monthly returns become more important than pure speculation. With the advent of the financialisation of rental housing 2.0, the long-term investment focus of these funds paradoxically enables a short-term investment focus by buying and selling shares in these funds on the stock exchange, thereby substituting pure speculative strategies in the housing market by those in the stock exchange_plus ça change, plus c'est la même chose. ${ }^{12}$ The dividing line between financialisation 1.0 and 2.0 therefore remains thin: some listed funds still adopt investment techniques typical of private equity funds and vice versa. In other words, we do not consider the endeavours of listed real estate companies as more "friendly" or "patient" per se; the creation of shareholder value is the prime consideration; both financialisation 1.0 and 2.0 constitute and reconstitute capital accumulation, either through pure speculation or through strategies of expanded reproduction (see AIShehabi and Suroor 2016).

Financialisation 1.0 and 2.0 highlight the dual nature of housing both as a place of survival and a site of accumulation (e.g. Soederberg 2017). Under the regime of Wohnungsgemeinnützigkeit ("common interest principle") housing was primarily valued for its use value, even though the exchange value was never completely out of sight and exploitation not completely averted, as such houses were still constructed and managed within a capitalist regime and often owned by private corporations. As the idea of Wohnungsgemeinnützigkeit was abandoned, 
many public, non-profit and corporate entities sold their housing stock to the highest bidder, opening up to the primitive accumulation of financialisation 1.0. At the time, use values - still important to tenants-became secondary to exchange values. With the shift from phase 1.0 to 2.0 we also witness a shift in how these exchange values are created: first primarily (but never exclusively) through pure speculation strategies of "buy low and sell high", and then primarily (but again not exclusively) through maximising rental returns and expanded reproduction. The long-term effects on housing affordability and displacement will, no doubt, be a topic of future research. Also, the ways in which listed real estate funds play "a transformative role in the transition from industrial to financial capitalism" (Kaika and Ruggiero 2016:5) deserves more attention.

In conclusion, we state that our real-world examples also have important implications for the "financialisation of rental housing 2.0" in other countries. As large housing portfolios have been put up for sale, the phenomenon of the global corporate landlord is becoming more widespread (Beswick et al. 2016; cf. Soederberg 2017). We conclude that more comparative research is necessary to denote the local and national varieties between countries and cities, but also between investment strategies. Further, it must be taken into account how these trends coincide with related developments, such as new innovations of social housing bonds, the revival of securitisation markets, the introduction of REIT-like systems across capitalist countries and the role of special-purpose vehicles and offshore finance in (re)funding real estate acquisitions and investment costs (Botzem and Dobusch 2017; Wainwright and Manville 2017). For better or worse, housing provision in presentday financialised capitalism becomes increasingly funded and managed by capital markets, a pattern which reminisces the late $19^{\text {th }}$ century (Harloe 1990; Kohl 2015). The arrival of listed real estate companies that invest in real estate assets is only the beginning of this trend. By the last turn of the century Neil Smith (2002:430) considered gentrification "generalised as a central feature of...urbanism"; with the advent of financialisation 2.0 we can consider financialisation increasingly becoming generalised as a central feature of urbanism.

\section{Acknowledgements}

The authors are grateful to Sinéad Kelly and Mirjam Büdenbender for their indispensable feedback on a previous version of this paper. We also thank Rodrigo Fernandez and Jannes van Loon for useful suggestions and Annia Martinez for her support during the fieldwork in Germany. Last but not least, we thank the editor and anonymous referees of this journal who helped to improve the work a lot. This work is part of "The Real Estate/Financial Complex" research project (European Research Council grant number 313376).

\section{Endnotes}

1 Rental housing in Germany is organised on the one hand in private housing and on the other hand in public (different state companies), non-profit (e.g. cooperative housing) and social housing (this is a special state financing scheme in order to enable lower rents for a limited time- mostly 10-20 years).

2 In this specific quote, Harvey (2005) understands the "privatised mainstream of capital accumulation" as the private market itself. However, in the spirit of his work on 
accumulation by dispossession, we see housing units really becoming part of the "mainstream" once the units become tradable as long-term investment objects on the stock exchange.

3 While finishing our paper, we became aware of a working paper that uses almost the same heuristic, but has a slightly different understanding of financialisation 2.0 (GarcíaLamarca 2017).

4 Under the state socialism of East Germany, housing construction was state-led and part of a planned economy. Upon German reunification, the institutions from the West were transferred to the East. Because of this "institutional transfer', German housing scholars usually focus on the post-war history of West Germany to describe the housing trajectory of the country as a whole. For the purposes of this paper, we do the same.

5 Before the large portfolio transactions in the late 1990s and early 2000s, housing companies in the former East and Berlin had already sold many of their individual housing units as they were legally obliged to compensate for the remission of old debts (Altschuldehilfe).

6 Every country has different legislations for listed real estate companies, mostly based around a REIT structure (KPMG 2013). In Germany, the G-REIT which has tax advantages compared with regular listed real estate companies was introduced in 2007. But while GREITs are only allowed to invest in housing units constructed after 2007, most listed real estate companies in Germany have adopted the legal structure of a joint-stock company (Aktiengesellschaft).

7 Here it must be noted that Immeo still considers Düsseldorf as an important market for their investments. Mainly the smaller cities in the Ruhr area, of which Mülheim an der Ruhr, Duisburg and Oberhausen are good examples, are considered non-strategic.

8 The German concept of Heimat (and, therefore, Heimaterde) does not have an equivalent in many European languages, including English. We have used a literal translation.

9 It has to be taken into account that German rent regulation makes a fundamental difference between maintenance which has to be paid by landlords and modernisation which has to be paid by tenants. Modernisation applies mostly to energy saving expenditures which should save energy. This is why the difference is an issue between both sides, although the German law rarely offers possibilities to oppose the modernisation (see Bürgerliches Gesetzbuch § 559).

10 Interestingly, the CEO of Innovation City and former mayor of Oberhausen, Burkhard Drescher, was the CEO of Deutsche Annington between 2008 and 2011.

11 Calculated on an annual average, rents can normally only increase with less than $7 \%$ on a three-year basis and not above the rental ceiling in the specific neighbourhood. Modernisation creates an incentive for listed real estate companies to increase the rents. Up to $11 \%$ of the modernisation costs can be added to the rents on an annual basis irrespective of whether or not the new rents are calculated above the rental ceiling. Moreover, the $11 \%$ increase is without time restrictions.

12 French proverb: "the more things change, the more they stay the same".

\section{References}

Aalbers M B (2016) The Financialisation of Housing: A Political Economy Approach. New York: Routledge

Aalbers M B and Holm A (2008) Privatising social housing in Europe: The cases of Amsterdam and Berlin. In K Adelhof, B Glock, J Lossau and M Schulz (eds) Urban Trends in Berlin and Amsterdam (pp 12-23). Berlin: Berliner Geographische Arbeiten, Humboldt Universität zu Berlin

AlShehabi O H and Suroor S (2016) Unpacking "accumulation by dispossession", "fictitious commodification", and "fictitious capital formation": Tracing the dynamics of Bahrain's land reclamation. Antipode 48(4):835-856

BBSR (2007) "Veränderung der Anbieterstrukturen im deutschen Wohnungsmarkt und wohnungspolitische Implikationen." Forschungen Heft 124, Bonn 
Bernt M, Colini L and Förste D (2017) Privatisation, financialisation, and state restructuring in East Germany: The case of "Am Südpark". International Journal of Urban and Regional Research. https://doi.org/10.1111/1468-2427.12521.

Beswick J, Alexandri G, Byrne M, Fields D, Hodkinson S and Janoschka M (2016) Speculating on London's housing future. City 20(2):321-341

Böhnke A (2015) Das Eltingviertel soll grüner werden. Der Westen 18 November https:// www.waz.de/staedte/essen/nord-west-borbeck/essener-eltingviertel-soll-gruener-werdenid11296688.html (last accessed 30 November 2017)

Boisnier C (2011) Les sociétés immobilières d'investissement cotées (SIIC) ou French REITs: foncière des régions et Unibail-Rodamco. Flux 3(85/86):89-104

Botzem S and Dobusch L (2017) Financialisation as strategy: Accounting for inter-organisational value creation in the European real estate industry. Accounting, Organisations, and Society 59:31-43

Byrne M (2016) "Asset price urbanism" and financialisation after the crisis: Ireland's National Asset Management Agency. International Journal of Urban and Regional Research 40(1):31-45

Coakley J (1994) The integration of property and financial markets. Environment and Planning A 26(5):697-713

Deeg R and Hardie I (2016) What is patient capital and who supplies it? Socio-Economic Review 14(4):627-645

Deschermeier P, Haas H, Hude M and Voigtländer M (2016) A first analysis of the new German rent regulation. International Journal of Housing Policy 16(3):293-315

Diamantis C (2013) "Abschlussbericht der Enquetekommission 'Wohnungswirtschaftlicher Wandel und neue Finanzinvestoren auf den Wohnungsmärkten in NRW'." Hrsg. Landtag Nordrhein-Westfalen, Düsseldorf (Drücksache 16/229)

Eckardt V (2015) Startschuss fürs Eltingviertel. Der Westen 16 April. http://www.derweste n.de/staedte/essen/startschuss-fuers-eltingviertel-id10568256.html (last accessed 30 November 2017)

EPRA (2013) Stock Exchange Listed Property Companies: Building a Stronger Europe. Brussels: European Public Real Estate Association

Fernandez R and Aalbers M B (2016) Housing and the variations of financialised capitalism. Competition and Change 20(2):71-88

Fichtner J (2014) Privateers of the Caribbean: The hedge funds-US-UK-offshore nexus. Competition and Change 18(1):37-53

Fields D (2015) Contesting the financialisation of urban space: Community organisations and the struggle to preserve affordable rental housing in New York City. Journal of Urban Affairs 37(2):144-165

Fields D (forthcoming) Constructing a new asset class: Property-led financial accumulation after the crisis. Economic Geography

Fields D and Uffer S (2016) The financialisation of rental housing: A comparative analysis of New York City and Berlin. Urban Studies 53(7):1486-1502

Foncière des Régions (2015) "Document de Référence 2015." Foncière des Régions, Paris

García-Lamarca M (2017) "Housing Dispossession and (Re)surging Rents in Barcelona: Financialised Housing 2.0?" Paper presented at the Finance, Crisis and the City: Global Urbanism and the Great Recession conference, Villa La Pietra, NYU Florence, 5-7 May

Grenz M (2016) Eltingstraße wird zum Wohnzimmer. Der Westen 3 July. http://www.derwe sten.de/staedte/essen/eltingstrasse-im-nordviertel-wird-zum-wohnzimmer-id11972999. html (last accessed 30 November 2017)

Hagenbucher R (2016) Das Eltingviertel blüht auf. Der Westen 7 June. http://www.derweste n.de/staedte/essen/nord-west-borbeck/das-eltingviertel-blueht-auf-oder-geht-ein-id 11893693.html (last accessed 30 November 2017)

Harloe M (1995) The People's Home? Social Rented Housing in Europe and America. Hoboken: Wiley-Blackwell

Harvey D (2005) The New Imperialism. Oxford: Oxford University Press

Heeg S (2013) Wohnen als Anlageform: Vom Gebrauchsgut zur Ware. Emanzipation-Zeitschrift für sozialistische Theorie und Praxis 3(2):5-20 
Helbrecht I and Geilenkeuser T (2012) Demographischer Wandel, Generationeneffekte und Wohnungsmarktentwicklung: Wohneigentum als Altersvorsorge? Raumforschung und Raumordnung 70(5):425-436

Hesselmann F-R (2015) Projekt an Max-Halbach-Straße mit der Stadt abgestimmt. Der Westen 4 July. http://www.derwesten.de/staedte/muelheim/projekt-an-max-halbach-strassemit-der-stadt-abgestimmt-id10846976.html (last accessed 30 November 2017)

Holm A (2010a) Institutionelle Anbieter auf deutschen Wohnungsmärkten - neue Strategien der Wohnungsbewirtschaftung. Informationen zur Raumentwicklung 5(6):391-402

Holm A (2010b) Privare heißt Rauben Zur Ökonomie von Wohnungsprivatisierungen. Zeitschrift Marxistische Erneuerung 21(83):46-59

Holm A (2015) "Neue Gemeinnützigkeit: Gemeinwohlorientierung in der Wohnungsversorgung." http://www.heidrun-bluhm.de/fileadmin/kreise/Bluhm/Neue_Gemeinnue tzigkeit_gesamt_2015-09-16.pdf (last accessed 1 December 2017)

IEIF (2014) "Annuaire des Sociétés immobilières cotées européennes. SIIC, REITs et foncières." IEIF les publications, Paris

Ince O U (2014) Primitive accumulation, new enclosures, and global land grabs: A theoretical intervention. Rural Sociology 79(1):104-131

Kaika M and Ruggiero L (2016) Land financialisation as a "lived" process: The transformation of Milan's Bicocca by Pirelli. European Urban and Regional Studies 23(1):3-22

Kaiser H-G (2008) "Die Entwicklung der Wohnungswirtschaft von Thyssen / Krupp bis Immeo Wohnen als Mitglied der Foncière des Régions." https://www.immeo.de/filead min/user_upload/downloads/PDFs/Die_Entwicklung_der_Wohnungswirtschaft_19.02. 2009.pdf (last accessed 1 December 2017)

Kirchner J (2007) The declining social rental sector in Germany. International Journal of Housing Policy 7(1):85-101

Kofner S (2012) "Aktuelle Geschäftsmodelle von Finanzinvestoren im Themenfeld Wohnungswirtschaftlicher Wandel und neue Finanzinvestoren." https://www.landtag. nrw.de/portal/WWW/GB_I/I.1/EK/16.WP/EK_I/Gutachten_Enquete_2011___EndEndfa ssung_Juli_2012_Arbeitsstand_24.02.2013....pdf (last accessed 1 December 2017)

Kofner S (2014) The German housing system: Fundamentally resilient? Journal of Housing and the Built Environment 29(2):255-275

Kohl S (2015) The power of institutional legacies: How $19^{\text {th }}$ century housing associations shaped $20^{\text {th }}$ century housing regime differences between Germany and the United States. European Journal of Sociology 56(2):271-306

KPMG (2013) "Taxation of Real Estate Investment Trusts: An Overview of the REIT Regimes in Europe, Asia and the Americas." https://home.kpmg.com/content/dam/kpmg/pdf/ 2014/02/taxation-real-estate-investment-trusts-v3.pdf (last accessed 1 December 2017)

Krippner G (2011) Capitalizing on Crisis: The Political Origins of the Rise of Finance. Cambridge: Harvard University Press

Lindgens J and Süselbeck K (2012) Immeo trennt sich von über 500 Wohnungen in Essen. Der Westen 12 October. https://www.derwesten.de/staedte/essen/immeo-trennt-sichvon-ueber-500-wohnungen-in-essen-id7186586.html (last accessed 1 December 2017)1

Lizieri C (2009) Towers of Capital: Office Markets and International Financial Services. Oxford: Wiley-Blackwell

Lizieri C and Pain K (2014) International office investment in global cities: The production of financial space and systemic risk. Regional Studies 48(3):439-455

Moreno L (2014) The urban process under financialised capitalism. City 18(3):244-268

Müller S (2012) "Wie Wohnen prekär wird. Finanzinvestoren, Schrottimmobilien und Hartz IV." Zentrale wissenschaftliche Einrichtung der TU Dortmund. http://www.sfs.tu-dort mund.de/sfs-Reihe/Band\%20181.pdf (last accessed 1 December 2017)

Murie A, Tosics I, Aalbers M, Sendi R and Černič Mali B (2005) Privatisation and after. In R van Kempen, Dekker K, Hall S and Tosics I (eds) Restructuring Large Housing Estates in Europe (pp 85-103). Bristol: Policy Press

Peck J (2012) Austerity urbanism. City 16(6):625-655

Pereira A (2017) The financialisation of housing: New frontiers in Brazilian cities. International Journal of Urban and Regional Research.https://doi.org/10.11111/1468-2427.12518 
Polanyi K (2001 [1944]) The Great Transformation: The Political and Economic Origins of Our Time. Boston: Beacon Press

Rutland T (2010) The financialisation of urban redevelopment. Geography Compass 4 (8):1167-1178

Scharmanski A (2013) "'Corephorie' und Alternativen. Institutionelle Immobilieninvestitionen 2013/2014." Quantum Fokus, 4. Quartal 2013. http://docplayer.org/8154733-Qua ntum-fokus-4-quartal-2013-corephorie-und-alternativen.html (last accessed 1 December 2017)

Schymiczek M (2015) Auf Stippvisite im Eltingviertel. Der Westen 26 August. http://www.de rwesten.de/staedte/essen/auf-stippvisite-im-eltingviertel-id11028079.html (last accessed 1 December 2017)

Smith N (2002) New globalism, new urbanism: Gentrification as global urban strategy. Antipode 34(3):427-450

Soederberg S (2017) The rental housing question: Exploitation, eviction, and erasures. Geoforum. https://doi.org/10.1016/j.geoforum.2017.01.007

Teresa B F (2016) Managing fictitious capital: The legal geography of investment and political struggle in rental housing in New York City. Environment and Planning A 48(3):465484

Uffer S (2011) "The Uneven Development of Berlin's Housing Provision." Unpublished PhD thesis, London School of Economics and Political Science

Unger K (2017) "Kohle machen über Tage." Rosa Luxemburg Stiftung. https://www.rosa lux.de/publikation/id/37832/kohle-machen-ueber-tage/ (last accessed 1 December 2017)

Van Loon J and Aalbers M B (2017) How real estate became "just another asset class": The financialisation of the investment strategies of Dutch institutional investors. European Planning Studies 25(2):221-240

Voigtländer M (2007) Die Privatisierung öffentlicher Wohnungen. Wirtschaftsdienst 87 (10):679-686

Voigtländer M (2010) Der Immobilienmarkt in Deutschland. Struktur und Funktionsweise. Berlin: Verband deutscher Pfandbriefbanken

Vonovia (2015) "Annual Report Vonovia SE 2015: It's Time To Rethink Housing." Vonovia SE

Vonovia and CBRE (2016) "Housing Market Report Germany 2016." Vonovia SE and CBRE $\mathrm{GmbH} 3$

Wainwright T and Manville G (2017) Financialisation and the third sector: Innovation in social housing bond markets. Environment and Planning A 49(4):819-838

Waldron R (2017) "Capitalizing on the Urban Debtscape: The Political Economy of Real Estate Investment Trusts and the 'Resolution' of the Crisis." Working Paper, Queen's University Belfast

Wijburg G and Aalbers M B (2017a) The alternative financialisation of the German housing market. Housing Studies 32(7):968-989

Wijburg G and Aalbers M B (2017b) The internationalisation of commercial real estate markets in France and Germany. Competition and Change 21(4):301-320

Wyly E, Newman K, Schafran A and Lee E (2010) Displacing New York. Environment and Planning A 42(11):2602-2623 


\section{Please correct and return this set}

Please use the proof correction marks shown below for all alterations and corrections. If you wish to return your proof by fax you should ensure that all amendments are written clearly in dark ink and are made well within the page margins.

\begin{tabular}{|c|c|c|}
\hline Instruction to printer & Textual mark & Marginal mark \\
\hline Leave unchanged & ... under matter to remain & ( ) \\
\hline $\begin{array}{l}\text { Insert in text the matter } \\
\text { indicated in the margin }\end{array}$ & $h$ & $\begin{array}{l}\text { New matter followed by } \\
h \text { or } h \otimes\end{array}$ \\
\hline Delete & $\begin{array}{l}\text { I through single character, rule or underline } \\
\text { or }\end{array}$ & $\sigma$ or $\sigma(x)$ \\
\hline $\begin{array}{l}\text { Substitute character or } \\
\text { substitute part of one or } \\
\text { more word(s) }\end{array}$ & I through letter or & $\begin{array}{l}\text { new character / or } \\
\text { new characters / }\end{array}$ \\
\hline Change to italics & — under matter to be changed & $\leftarrow$ \\
\hline Change to capitals & $\equiv$ under matter to be changed & $\equiv$ \\
\hline Change to small capitals & $=$ under matter to be changed & $=$ \\
\hline Change to bold type & $\sim$ under matter to be changed & $\sim$ \\
\hline Change to bold italic & $\bar{\sim}$ under matter to be changed & $\underline{s i n}$ \\
\hline Change to lower case & Encircle matter to be changed & $\Rightarrow$ \\
\hline Change italic to upright type & (As above) & \\
\hline Change bold to non-bold type & (As above) & \\
\hline Insert 'superior' character & $\begin{array}{l}/ \text { through character or } \\
K \text { where required }\end{array}$ & $\begin{array}{l}y^{\prime} \text { or } y \\
\text { under character } \\
\text { e.g. } y^{2} \text { or } y^{2}\end{array}$ \\
\hline Insert 'inferior' character & (As above) & $\begin{array}{l}\lambda \\
\text { over character } \\
\text { e.g. } \hat{\Sigma}\end{array}$ \\
\hline Insert full stop & (As above) & $\odot$ \\
\hline Insert comma & (As above) & , \\
\hline Insert single quotation marks & (As above) & $\begin{array}{l}\dot{y} \text { or } \dot{x} \text { and/or } \\
\dot{y} \text { or } \dot{y}\end{array}$ \\
\hline Insert double quotation marks & (As above) & $\begin{array}{l}\ddot{y} \text { or } \ddot{y} \text { and/or } \\
\ddot{y} \text { or } \ddot{y}\end{array}$ \\
\hline Insert hyphen & (As above) & 1 \\
\hline Start new paragraph & 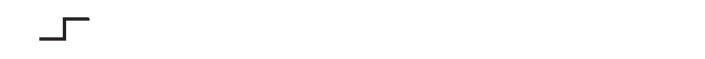 & 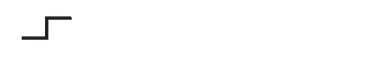 \\
\hline No new paragraph & $\infty$ & $\omega$ \\
\hline Transpose & $\sqcup$ & $\sqcup$ \\
\hline Close up & linking $\bigcirc$ characters & \\
\hline $\begin{array}{l}\text { Insert or substitute space } \\
\text { between characters or words }\end{array}$ & $\begin{array}{l}\text { I through character or } \\
\Lambda \text { where required }\end{array}$ & \\
\hline $\begin{array}{l}\text { Reduce space between } \\
\text { characters or words }\end{array}$ & $\begin{array}{l}\text { between characters or } \\
\text { words affected }\end{array}$ & $\uparrow$ \\
\hline
\end{tabular}

